\title{
Regional Energy Planning: Optimising Geothermal Energy Production Under Natural Conditions
}

\author{
Marcin RABE ${ }^{I}$, Dalia STREIMIKIENE ${ }^{2 *}$, Adam WOJCIECHOWSKI ${ }^{3}$ and Magdalena \\ SOCHACKA ${ }^{4}$
}

Authors' affiliations and addresses:

${ }^{1}$ Institute of Management, WEFiZ University of

Szczecin

e-mail: marcin.rabe@wzieu.pl

${ }^{2}$ Institute of Economics and Rural Development, Lithuanian Centre for Social Sciences, A.

Vivulskio g. 4A-13, LT-03220 Vilnius, Lithuania, Lithuania

e-mail: dalia@mail.lei.lt

${ }^{3}$ Institute of Information Technology, Lodz University of Technology, Wolczanska 215, Lodz, Poland

e-mail: adam.wojciechowski@p.lodz.pl

${ }^{4}$ Faculty of Health Sciences, Pomeranian Medical University in Szczecin

e-mail: magdalena_soch@wp.pl

*Correspondence:

Dalia Streimikiene, Institute of Economics and Rural Development, Lithuanian Centre for Social Sciences, A. Vivulskio g. 4A-13, LT-03220

Vilnius, Lithuania, Lithuania

e-mail:dalia@mail.lei.lt

How to cite this article:

Rabe, M., Streimikiene, D., Wojciechowski, A. and Sochacka, M. (2021). Regional Energy

Planning: Optimising Geothermal Energy

Production Under Natural Conditions. Acta

Montanistica Slovaca, Volume 26 (4), 784-795.

DOI:

https://doi.org/10.46544/AMS.v26i4.15

\begin{abstract}
Geothermal energy can be an attractive source of renewable energy in many respects. The purpose of this paper is to assess the role of geothermal energy in the West Pomeranian Region of Poland. The article presents the key principles of geothermal energy development, its role, functions and perspectives in fostering renewable energy usage in the region in question. Strengths, weaknesses as well as opportunities and threats of using geothermal energy are analysed based on the literature review. A regional geothermal energy development model is proposed. The study is based on statistical data. The results of the conducted study show that geothermal energy can be an important source of regional energy supply in the West Pomeranian Region. However, advantages and shortcomings should be taken into account when deciding on the promotion of geothermal energy in the selected region.
\end{abstract}

\section{Keywords}

Geothermal energy, geothermal energy optimisation model, natural conditions, regional energy planning. 


\section{Introduction}

The main energy and climate policy of the EU is to facilitate the transition away from fossil fuels towards the so-called "zero free energy" and to deliver on the EU's Paris Agreement commitments for reducing greenhouse gas emissions (GHG) emissions. The Clean energy for all Europeans package describes the most important steps towards the implementation of the energy union strategy, thus delivering to the carbon-free economy target of 2050. The EU has set an ambitious 2030 target of having 32\% for renewable energy sources (RES) in the final energy consumption volume. The EU member states have prepared their RES commitments and policy packages to support RES and overcome market barriers for faster penetration of renewables. In addition, renewables provide important opportunities for sustainable regional development and the creation of sustainable energy areas, in particular, energy clusters and energy cooperatives (Raszkowski \& Bartniczak, 2018; Savitz \& Gavriletea, 2019; Liao et al., 2019; Mariyakhan et al., 2020; Popp et al. 2018). Support for the development of distributed energy generation in energy clusters and energy cooperatives is particularly important from the viewpoint of regional energy systems' planning (Shindina et al., 2018). Among many unconventional sources of energy, geothermal energy has recently become the centre of attention. This type of energy is the Earth's natural heat, accumulated in soils, rocks, waters and vapours filling pores and rock crevices. Enormous amounts of energy are generated in the nucleus, mantle and the Earth's crust. The temperature of the Earth's interior changes with depth and, starting from its surface, increases by approx. 300C per kilometer (Szramka \& Różycki, 1999). Poland has natural conditions favourable for the direct use of geothermal energy. The waters currently available for exploitation occur at the depths of about $4 \mathrm{~km}$ have temperatures varying from about 20 to 80-950C (Sala, 2018; Dudin et al., 2019). Therefore, the country has good natural conditions to use this potential for district heating development in specific regions of Poland. The following indicators are set in the main Polish energy policy document for 2030 (Ministry of. Energy, 2018): to achieve $60 \%$ share of coal in power generation and $21 \%$ RES in the final energy consumption; improvement in energy efficiency by $23 \%$ as compared to the 2007 level and reducing $\mathrm{CO}_{2}$ emissions by $30 \%$ as compared with the 1990 level. The introduction of new nuclear energy is also scheduled for 2033. However, there are important barriers that hamper the use of geothermal energy at local, national, and European levels (Ozgener, 2010; Colmenar-Santos et al., 2018; Romero-Rubio \& de Andrés Díaz, 2015; Büyüközkan \& Güleryüz, 2017). Therefore, policies and measures need to be taken to overcome these barriers (Boie et al., 2014; Borge-Diez et al., 2015; Lu et al., 2019).

Though Poland has set ambitious targets for renewable energy development in line with the EU energy and climate framework for 2030 and 2050, there are no studies dealing with forecasting geothermal energy development based on local natural conditions of specific regions and integration of a geothermal component into regional energy planning. The paper aims to overcome this gap and proposes the tools for optimisation of geothermal energy development in the selected region in order to implement energy and climate targets in Poland and move faster towards a carbon-free economy.

The aim of this paper is to assess the role of geothermal energy use in the West Pomeranian Region. In order to achieve this aim, the principles of geothermal energy development, its role and functions, strengths, weaknesses as well as opportunities and threats of using geothermal energy should be defined. The current situation with geothermal energy usage and the potential of geothermal energy development based on natural conditions in the West Pomeranian Region need to be analysed. Our analysis results in the construction of an optimisation model. The rest of the paper is structured in the following way: section 1 reviews the literature on strengths, weaknesses and opportunities of geothermal energy development; section 2 presents the overview of natural conditions in the selected Polish region in terms of geothermal energy exploitation and assesses the current situation and the potential of geothermal energy resources used in the region along with the policies promoting RRS; section 3 presents our own optimisation model for regional geothermal energy in the selected region; section 4 discusses the case study results and section 5 concludes.

\section{Literature Review}

Geothermal energy, also called geothermal energy or geothermal energy, involves the use of thermal energy inside the Earth. In the case of geothermal energy, the fact that the Earth's temperature rises with depth, reaching $6600^{\circ} \mathrm{C}$ in the very core, is used. Geothermal energy escapes to the Earth's surface naturally, with the power determined at approx. 46 TW (Hollenbach \& Herndon, 2001). However, given the huge volume of the Earth, its geothermal resources are almost inexhaustible. It is estimated that geothermal deposits worldwide are around $8 \times$ $1012 \mathrm{EJ}$ (one EJ is equivalent to 27.3 billion $\mathrm{m} 3$ of gas). According to some sources, geothermal resources usually have a life span of 30 to 60 years, which means that in world literature view on quasi-renewable geothermal energy (Kaczmarczyk, 2009).

The literature divides geothermal energy into two groups: hydrothermal and geothermal. Hydrothermal resources are water, steam or a mixture of water vapour found in rock crevices or in water veins. In contrast, petrothermal resources occur in rock layers (Collins et al., 2017). 
Geothermal energy is taken in by means of boreholes, into which cool water is pumped in and removed hot, heated from hot rocks. It also occurs as a natural source of heat in thermal sources. Geothermal energy is used in approx. 80 countries and the total power of operating geothermal power plants was estimated in 2015 at 1264 MWe. The forecasts for the development of geoelectroenergetics assume that in 2020 the power of the power plant will amount to $21400 \mathrm{MWe}$ (Bertani, 2015). The world's largest producers of electricity from geothermal energy are presented in Table 1.

\begin{tabular}{l} 
Tab. 1. The world's largest producers of electricity from geothermal energy in 2015 \\
\begin{tabular}{|c|c|}
\hline Country & Generated energy (GWh) per year \\
\hline United States & 16600 \\
\hline Philippines & 9646 \\
\hline Indonesia & 9600 \\
\hline New Zealand & 7000 \\
\hline Mexico & 6071 \\
\hline Italy & 5660 \\
\hline
\end{tabular} \\
\hline
\end{tabular}

Due to the operating principle, geothermal power plants are classified into three groups, including dry steam power plants, wet steam power plants and intermediary power plant (Table 2). The type of power plant results from the acquired geophysical fluid (Cucchiella et al., 2018).

Tab. 2. Dependencies of geothermal power plants on the temperature of the geothermal fluid

\begin{tabular}{|c|c|}
\hline Geoply temperature $\left({ }^{\circ} \mathbf{C}\right)$ & Power plant types \\
\hline $180-300$ & Direct system (dry steam) \\
\hline $200-320$ & Water expansion system (wet steam) \\
\hline $125-165$ & System with an intermediate factor (saw system) \\
\hline
\end{tabular}

(Source: Stachel \& Sottysik, 2017)

For the production of electricity, water is used in the form of steam at very high temperatures, above $150^{\circ} \mathrm{C}$. Water with a lower temperature is mainly used for heating or cooling rooms, greenhouse farming, and bathing and balneology. Sources with temperatures above $150^{\circ} \mathrm{C}$ are found only in some regions of the globe. In the European Union, geothermal heating plants already operate in Iceland, Greece, Italy, Turkey, Germany and Austria. In Iceland, $30 \%$ of homes use electricity generated from geothermal energy (Kubski, 2017).

As with all types of energy sources, geothermal energy has its strengths and weaknesses and creates opportunities and threats (Table 3 ).

Tab. 3. Analysis of strengths and weaknesses of geothermal energy in the world

\begin{tabular}{|c|c|c|c|}
\hline Strengths & Weakness & Chances & Threats \\
\hline
\end{tabular}

(Source: IEA, 2003)

Enthusiasts of geothermal solutions are convinced that its most important advantages include low environmental impact. It does not cause any pollution if it works correctly. Contrary to wind or solar energy, geothermal energy resources are always available, regardless of weather conditions, which affects the profitability of investments and relatively low operating costs, creating at the same time many new jobs (Rzepa, 2018; Kasperowicz et al., 2017).

Moderate optimists, recognising the fact of their abundance in us, emphasise that the energy obtained from them can only be a complementary source, and in regions where it has been shown to be profitable and competitive with other carriers (Maciej \& Nowak, 2017). 
Opponents of geothermal solutions are convinced that the disadvantage of geothermal energy is high investment costs and a long payback period. It is expensive to drill a well depth. The construction of installations in the form of pumps, heat exchangers, pumping stations and pipelines is also a heavy burden. The problem is the high mineralisation of some sources, which causes the deposition of salt on the internal surface of the installation's equipment (Olejnik, 2005).

\section{Geothermal Energy Development in Poland and West Pomeranian Region}

\section{Natural Conditions for Geothermal Energy in Poland}

Poland has a very good geothermal situation, despite being outside volcanic areas. Three geothermal provinces cover over $80 \%$ of the country. The water temperature in these provinces ranges from 30 to $130^{\circ} \mathrm{C}$, and the depth of occurrence in sedimentary rocks ranges from 1 to $10 \mathrm{~km}$ (Majorowicz, 1971).

The Polish Lowland province covers an area of $222,000 \mathrm{~km}^{2}$, and deposit temperatures range from 30 to $130^{\circ} \mathrm{C}$, at a depth of $1 \mathrm{~km}$ to $3 \mathrm{~km}$. The potential of geothermal resources was estimated at over 32458 million tons of water containing heat energy.

The pre-Carpathian province covers an area of $17,000 \mathrm{~km}^{2}$, and reservoir temperatures range from 25 to $50^{\circ} \mathrm{C}$. The potential of geothermal resources was estimated at 1555 million tons of water containing heat energy (Institute for Renewable Energy, 2011).

Whereas the Carpathian province covers an area of 12 thousand $\mathrm{km}^{2}$. The potential of geothermal resources was estimated at over 714 million t of waters containing thermal energy (Bujakowski, 2003).

The capacity to use geothermal waters concerns $40 \%$ of the country's area and extraction is profitable when the temperature reaches $65^{\circ} \mathrm{C}$ up to a depth of $2 \mathrm{~km}$, and the salinity does not exceed $30 \mathrm{~g} / \mathrm{l}$ (Sowiżdżał, 2009).

In Figure 1, the geothermal installations in Poland are mapped.

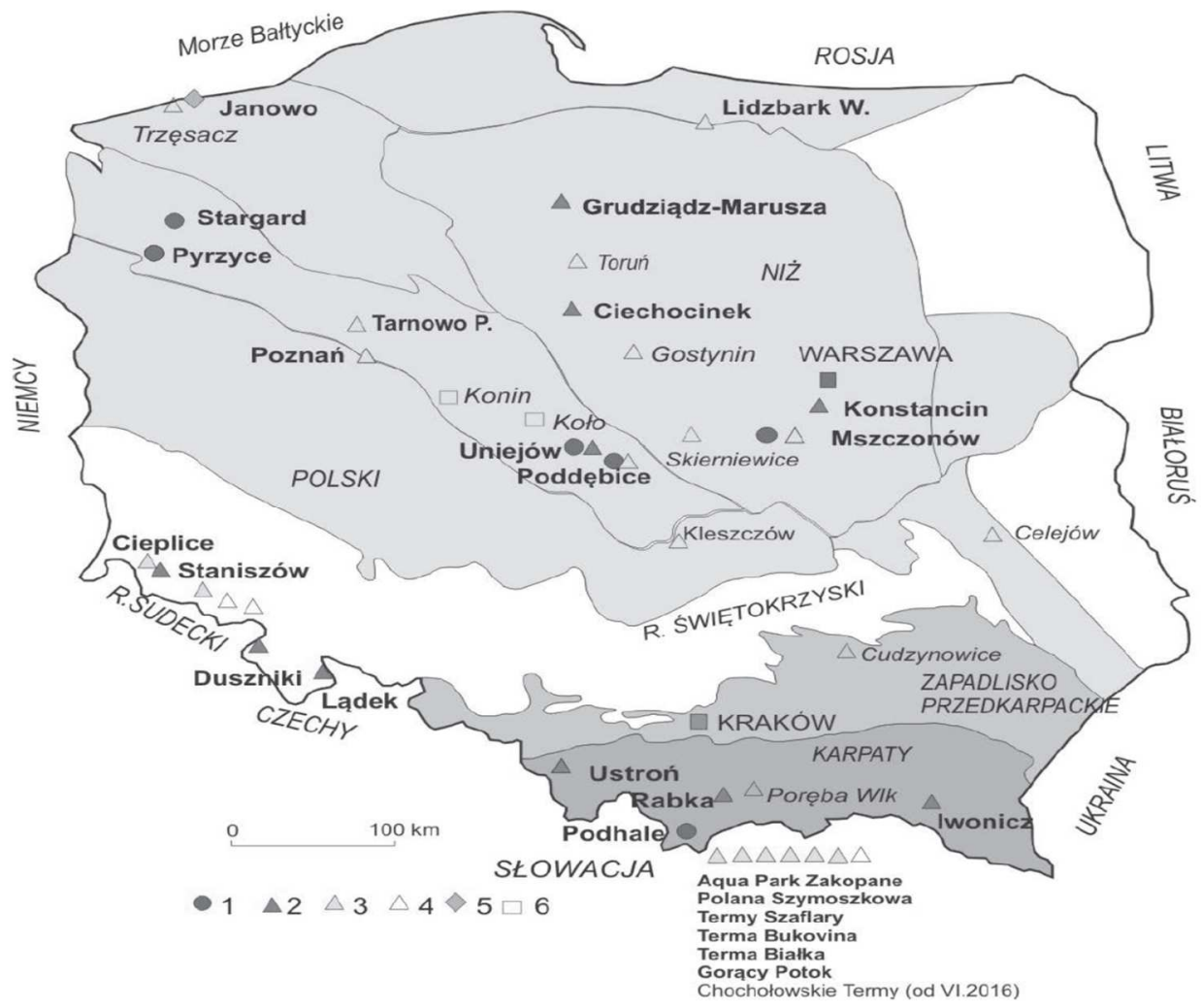

Fig. 1. Geothermal installations in Poland (Source: Kępińska, 2016)

\section{Geothermal Energy Resources in the West Pomeranian Region}

West Pomeranian Region is located in the Province of Polish Lowland in the Szczecin-Łódź geothermal district. In the central part of the province, there is a so-called tectonic area Szczecinski basin, covering the surroundings of Drawno, Drawsko Pomorskie, Chociwel, Nowogard, Goleniów, Police, Szczecin, Pyrzyce, Stargard and Dobrzany (Rabe, 2017).

The volume of geothermal resources of the Szczecin basin is presented in Table 4. 
Tab. 4. Geothermal resources of the Szczecin basin

\begin{tabular}{|c|c|}
\hline Resource Group & The volume of resources expressed in the TOE \\
\hline Available geothermal resources & $1,1 \times 10^{11} \mathrm{TOE}$ \\
\hline Static resources of geothermal energy & $1,13 \times 10^{10} \mathrm{TOE}$ \\
\hline Static resources - recoverable geothermal energy & $2,27 \times 10^{9} \mathrm{TOE}$ \\
\hline Available resources & $\mathbf{6 , 9 8} \times \mathbf{1 0}^{\mathbf{6}}$ TOE \\
\hline
\end{tabular}

(Source: Sowiżḋat, 2009)

The best geothermal disposable resources of the Szczecin basin include within its reach such cities as Stargard, Dobra, Chociwel, Ińsko and Dobrzany, where the potential was determined at over $35 \mathrm{MJ} / \mathrm{m}^{2}$. (Disposable resources - the amount of free hydro-geothermal water level or other balance units, possible to be managed under given environmental conditions, but without indicating the detailed location and technical and economic conditions of the water intake). Temperatures in this area range from 73 to $90^{\circ} \mathrm{C}$, to a depth of -2500 to -2000 m a.s.l. Relative geothermal conditions of available resources can boast of such municipalities as Goleniów, Police, Maszewo and the city of Szczecin, where the water temperature is from 50 to $60^{\circ} \mathrm{C}$ (Regional Office for Spatial Management of the West Pomeranian Region, 2018). The most favourable conditions for the construction of geothermal heating plants in the West Pomeranian Region are given in Table 5.

Tab. 5. Cities with the most favourable conditions for the construction of geothermal heating plants in the West Pomeranian Region

\begin{tabular}{|c|c|c|}
\hline $\begin{array}{c}\text { Very good conditions } \\
\text { for the construction of heating plants } \\
\text { geothermal facilities. }\end{array}$ & $\begin{array}{c}\text { Good conditions for construction } \\
\text { geothermal heating plants }\end{array}$ & $\begin{array}{c}\text { Relatively good conditions for } \\
\text { construction of geothermal heating } \\
\text { plants }\end{array}$ \\
\hline Szczecin & Choszczno & Dębno \\
\hline Police & Gryfino & Recz \\
\hline Goleniów & Gostyń & Myślibórz \\
\hline
\end{tabular}

(Source: Sala, 2018)

In another part of the Szczecin basin, the disposable geothermal energy resources are much smaller. In the eastern part of the province, the temperature of geothermal waters is around $20-30^{\circ} \mathrm{C}$. Sufficient conditions for the use of this type of energy are found in the following counties: Police, Goleniów, Szczecin, Pyrzyce, Choszczno, Stargard, parts of Gryfino, Łobeski, Drawski, Wałecki, Myślborski (Stachel \& Sołtysik, 2017).

The available geothermal energy resources in the West-Pomeranian region are mapped in Figure 2.

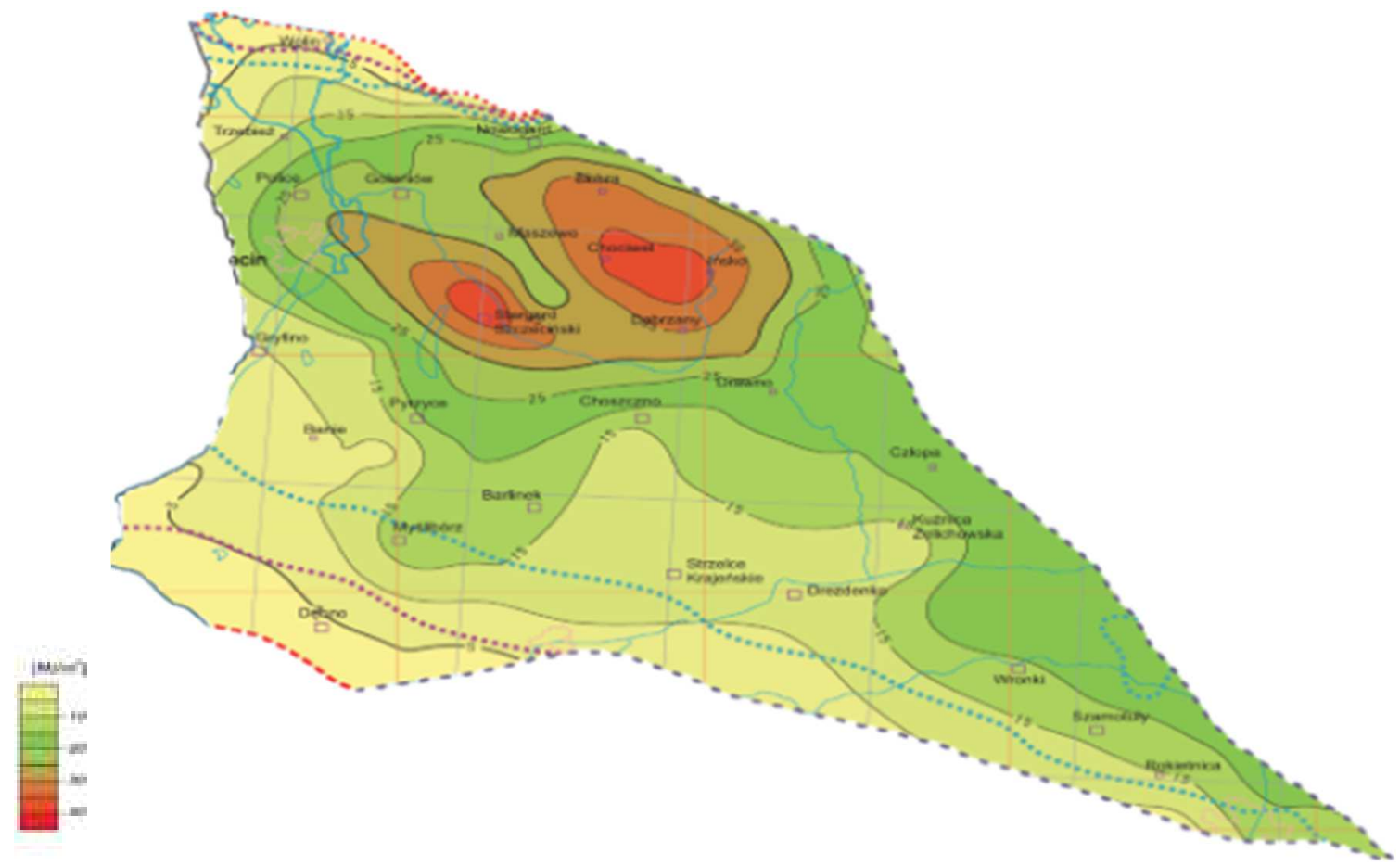

Fig. 2. Map of the unit available geothermal energy resources in the West Poland province (Source: Sowiżżat, 2009)

The heating plant in Pyrzyce was established in 1997. It uses geothermal water extracted from a depth of 1500-1700. Its exploitation is carried out by means of two production holes and two absorbent ones. The approved 
capacity is a total of about $370 \mathrm{~m}^{3} / \mathrm{h}$ water with an outlet temperature of $64^{\circ} \mathrm{C}$. The saltwater table is located 32 meters underground. After the system's modernisation and optimisation in recent years, the total installed capacity of the heating plant is about $22 \mathrm{MW}$, with about $16 \mathrm{MW}$ coming from gas boilers and $6 \mathrm{MW}$ from geothermal energy (heat exchangers). 20.4 MW comes from the absorption heat pump. The extracted geothermal water is sufficient to heat running water in flats in the summer and autumn. In winter, it is necessary to use gas heat pumps to heat water to $70-80^{\circ} \mathrm{C}$. At the moment, around $90 \%$ of all heat consumers in this 13,000 city are connected to the central heating network.

The Geothermal plant located in Stargard has a capacity of 14 MW. The geothermal intake is characterised by a high water temperature of about $90^{\circ} \mathrm{C}$. The operating system is two-hole; the extraction hole and the absorption hole are working. At the moment, about $60 \%$ of residents are connected to the central heating network, in this city of 75 thousand. It is worth noting that this is the second installation in Poland (after Podhale) in terms of annual production and sale of geothermal heat (Płocharski, 2017).

\section{Prospects for the Development of Geothermal Energy in the West Pomeranian Region}

A particularly important area for the energy direction of geothermal development in the West Pomeranian Region is broadly understood as heating (room heating, agriculture, other areas where heat is needed), which would significantly reduce the consumption of traditional fuels and pollutant emissions and increase the share of renewable energy in many cities (Regional Office for Spatial Management of the West Pomeranian Region, 2018).

The region has very good conditions for exploiting geothermal waters, thanks to its location. These waters can be used in thermal energy. The disposable volume in the region is 6.98 x $106 \mathrm{TOE}$ (a ton of oil equivalent).

Taking into account investment costs, this type of heating system should be located only in places where there will be a significant number of heat recipients. The preferred cities for the development of geothermal energy are Szczecin, Police, Goleniów and Nowogard. Currently, there is also an increase in the use of all types of compressor heat pumps (Rabe et al., 2019b).

Recreation and health care are also promising branches of use. They must meet the criteria of appropriate temperature, mineralisation and intake efficiency. Mineralisation of water for therapeutic purposes should not exceed $50 \mathrm{~g} / \mathrm{dm}^{3}$ and a minimum temperature of $28-42^{\circ} \mathrm{C}$, while for recreational purposes, $30 \mathrm{~g} / \mathrm{dm}^{3}$ and a minimum temperature of $24-30^{\circ} \mathrm{C}$, respectively. The most predisposed to use geothermal waters of the lower Jurassic ceiling for therapeutic and recreational purposes (due to its favourable mineralisation and temperature parameters) are the municipalities located in the poviats of Gryfińskie, Myśliborski, Choszczeński and Wałecki as well as partly Goleniowski, Łobeskie and Drawski (Rabe et al., 2019a).

In special cases, in the West Pomeranian Region, it would be possible to produce electricity using waters with temperatures above $80-100^{\circ} \mathrm{C}$, in binary installations with low power, usually in cogeneration with heat. With currently known technologies, the production of electricity from a geothermal source must have a minimum temperature of $80-90^{\circ} \mathrm{C}$ (IEA, 2003).

Another application of geothermal heat may be drying wood. Such facilities are already located at IGSMiE PAN in Podhale, as well as heating the football pitch and walking paths or in fish farming.

Convincing arguments that the given methods of geothermal energy management in the West Pomeranian Region on a larger scale than before are possible and economically effective, it provides the observed development and implementation of many investment projects in Europe (Kępińska, 2016).

\section{Policies to Promote Geothermal in Poland}

The Polish Energy Policy 2040, the main energy policy document in Poland, established the requirement that the share of RES in final energy consumption will reach $21 \%$ in 2030 . This RES target in final energy consumption also includes a $27 \%$ share of RES in power generation and district heating and cooling. It is foreseen that in the heating and cooling sector, the share of RES should grow by 1-1.3\% annually. The use of energy from biomass and biogas, geothermal energy, heat pumps, and solar energy will contribute to RES target in heating and cooling, while the power sector will be solar, offshore and offshore wind energy, energy from biomass and biogas, and hydropower. However, the changing business environment and technological development constitute major challenges for the heating and cooling sector in Poland. Important issues to be addressed in this sector are the changing of heat market model and tariff policy, extending the obligation to connect consumers to an energyefficient heating system and developing network infrastructure, regulating district cooling, etc. (Ministry of Energy, 2018).

The Energy Policy for Poland 2040 emphasises that district heating is one of Poland's main strategic directions of energy policy. The main policies and measures to ensure penetration of RES in this are the following: financial, organisational and legal support, by increasing the use of RES and waste in district heating as well as modernising and expanding heating systems and developing new RES technologies for this sector and promoting heat storage facilities and smart networks. 
However, support for RES should be based on competitive systems and the least cost decisions to achieve RES targets. Support will be provided in the form depending on the type of source and its size in these forms (Ministry of Energy, 2018):

- auctions - designated for sources generating energy in a manner suitable for commercial purposes;

- feed-in tariff system and feed-in premium system - targeted on the lowest capacity sources and applied to manage energy which is not consumed by small producers;

- grants and repayable aid - a mechanism depending on local needs, distributed in regions;

- a guarantee of origin - a voluntary support instrument - in the form of a certificate; demand for these instruments is generated by consumers who wish to be perceived as environment-friendly companies;

- aid mechanisms targeted on special technologies - a solution designated for sources for which there is no competition in the market, but their implementation is important for the country.

The auction offers permanent and stable conditions for investing in new RES installations. The auctions enable to channel aid to selected sectors based on least costs, energy security, technical criteria and the needs of local communities (Stavytskyy et al., 2018; Tvaronavičienė et al., 2018). Therefore, a stable and competitive RES support system is necessary to promote RES, including geothermal penetration in the energy markets, without increasing energy prices or serious disturbances in energy markets. Such economic measures implemented to support RES and necessary legal regulations will contribute to the dynamic growth of new investments in RES. The use of geothermal and heat pumps technologies is envisaged. The geothermal power generation - although at present its use is at a relatively low level, it is estimated to grow at a very fast rate. Major financial expenditures are required to determine geothermal potential, with the degree of certainty being very small, but the use of this type of energy may determine the development of a given region. Heat pumps used in households have become more and more common. Their potential is assessed to be at a level similar to geothermal energy generation. Electricity is required for them to be used, and linking installations with another RES which generates electricity is a good solution.

It is expected that Poland will rely on its own resources to implement the RES target. However, no excess energy production from RES is envisaged, which could be transferred to the other Member States in order for them to achieve their national RES contributions in 2030 (Ministry of Energy, 2018). The new Directive on the promotion of the use of energy from renewable sources (RED II) introduces new obligations for the share of RES in the heating and cooling sector. The heat sector needs funds at the local government level; therefore, the financing should be ensured by municipal utility companies usually having financial problems. The grants, repayable instruments, guarantee funds can be used to provide support to these utilities. This new directive (RED II) emphasises the importance of sustainable energy areas, in particular energy clusters and energy cooperatives. The support for the development of distributed energy generation in energy clusters and energy cooperatives is particularly important from the point of view of the construction of generation sources, networks and control systems in Poland. It is planned that ca. 300 energy sustainable areas will operate at the local level in Poland in 2030. The proposed form of financing: grants, repayable aid, guarantee funds (Ministry of Energy, 2018).

The emission allowance trading system (EU ETS) is the most important market-based mechanism aiming at GHG emission reduction and having a direct impact on the increase of competitiveness of renewables due to internalisation of external costs of fossil fuel generation and increase of energy price of fossil fuel-based plants. Installations eligible for the system belong to specific sectors or meet the defined threshold conditions set out in Directive 2003/87/EC. The number of installations covered by the scheme changes from one year to another (ca. 800 installations in Poland). The modernisation and innovation funds and the continuation of the currently applicable derogation system for the power sector will be introduced from 2021, within the framework of the EU ETS.

\section{Geothermal Energy Development Model in the West Pomeranian Region}

The publication presents a renewable energy development model that optimises the regional potential of geothermal energy. According to the Potential report and the use of renewable energy sources in the production of electricity and heat in the West Pomeranian Region, the potential of geothermal waters in the studied area can be used in the broadly understood heating sector. Only in some cases in the West Pomeranian Region, it is possible to produce electricity using waters with temperatures above $80-100^{\circ} \mathrm{C}$. It is estimated that the volume of available resources in the province is $6.98 \times 106 \mathrm{TOE}(81177400000 \mathrm{kWh})$, of which only 1 per cent of the available geothermal resources can be used to produce electricity $(811,744,000 \mathrm{kWh})$. Available geothermal resources are distinguished temperatures that make them very unattractive from the point of view of electricity generation.

The lexicographic method was used in the geothermal energy development model, which allowed to obtain a compromise solution (Rabe et al., 2020; Ślusarczyk et al., 2016; Popp et al., 2018; Mikita et al., 2017). ACCORDING TO THOMSON REUTERS, the EUA allowance price forecast for 2021-2030 was also used. The time range of empirical research was set for 2018-2030. 25 decision variables were adopted in the model, where the technical and economic parameters were calculated first, and the minimum or maximum levels of balance 
conditions were established (Rabe et al., 2019a). The average cost of energy production from various energy carriers (as of 2018) for the model are provided in Table 6.

Tab. 6. The average cost of energy production from various energy carriers (as of 2018)

\begin{tabular}{|c|c|}
\hline Name of the technology & Cost of electricity production PLN / kWh \\
\hline Conventional energy & 0.72 \\
\hline Energy from co-firing & 0.93 \\
\hline Solar power stations & 0.40 \\
\hline Wind farms & 0.24 \\
\hline Biomass power plants & 0.28 \\
\hline Hydroelectric power plants & 0.20 \\
\hline Geothermal power plant & 0.28 \\
\hline Energy from biogas plants & 0.70 \\
\hline Energy from biofuels & 1.10 \\
\hline
\end{tabular}

Objective function parameters from x1 to x15 include energy production costs, ecological costs, certificates, and EUA allowance prices (Table 7).

\begin{tabular}{|c|c|c|c|c|c|c|c|c|c|c|c|c|c|c|c|}
\hline $\begin{array}{c}\text { Types of } \\
\text { energy }\end{array}$ & $x_{1}$ & $x_{2}$ & $x_{3}$ & $x_{4}$ & $x_{5}$ & $x_{6}$ & $x_{7}$ & $x_{8}$ & $x_{9}$ & $x_{10}$ & $x_{11}$ & $x_{12}$ & $x_{13}$ & $x_{14}$ & $x_{15}$ \\
\hline $\begin{array}{c}\text { Costs of } \\
\text { production }\end{array}$ & 0.72 & 0.93 & 0.20 & 0.20 & 0.40 & 0.24 & 0.24 & 0.24 & 0.70 & 0.70 & 0.70 & 1.10 & 0.28 & 0.28 & 0.28 \\
\hline $\begin{array}{c}\text { Cost of the } \\
\text { certificate }\end{array}$ & 0.00 & 0.00 & 0.12 & 0.12 & 0.12 & 0.12 & 0.12 & 0.20 & 0.12 & 0.12 & 0.2 & 0.12 & 0.12 & 0.20 & 0.12 \\
\hline $\begin{array}{c}\text { Ecological } \\
\text { costs } \\
\text { cost of EUA } \\
\text { allowances) }\end{array}$ & 0.0316 & 0.0252 & 0.0006 & 0.0006 & 0.0007 & 0.0006 & 0.0006 & 0.0006 & 0.0116 & 0.0116 & 0.012 & 0.012 & 0.0004 & 0.0004 & 0.001 \\
\hline $\begin{array}{c}\text { Total costs } \\
\text { Tof }\end{array}$ & 0.69 & 0.90 & 0.07 & 0.07 & 0.27 & 0.11 & 0.11 & 0.03 & 0.56 & 0.56 & 0.56 & 0.96 & 0.15 & 0.07 & 0.15 \\
\hline
\end{tabular}

Whereas the parameters of the objective function, from $x_{16}$ to $x_{25}$, include costs of producing energy from energy crops (Table 8).

Tab. 8. Cost of energy production from energy crops (in $\mathrm{kWh} / \mathrm{ha}$ )

\begin{tabular}{|c|c|c|c|c|c|c|c|c|c|}
\hline Energy resources & $x_{17}$ & $x_{18}$ & $x_{19}$ & $X_{20}$ & $x_{21}$ & $x_{22}$ & $x_{23}$ & $x_{24}$ & $x_{25}$ \\
\hline Manufacturing cost & 0.18 & 0.35 & 0.17 & 0.07 & 0.04 & 0.5 & 0.34 & 0.5 & 0.21 \\
\hline
\end{tabular}

The author's model also assumes that, in 2030, energy production in the study area will amount to $11,956.08$ GWh. The price of allowances in 2030 will be at the level of 23.04 euros, i.e. 0.14 PLN per kWh.

The following decision variables have been applied to the model:

$x_{1}$ - generating non-renewable energy $(\mathrm{kWh})$;

$x_{2}$ - generating energy from co-firing $(\mathrm{kWh})$;

$x_{3}$ - generating water energy $(\mathrm{kWh})$ from existing installations (until the end of 2017);

$x_{4}$ - hydropower generation $(\mathrm{kWh})$ in new installations (from January 2018);

$x_{5}$ - solar energy generation $(\mathrm{kWh})$;

$x_{6}$ - generating energy from windmills at domestic $(\mathrm{kWh})$;

$x_{7}$ - generating energy from wind farms (kWh) from existing installations (until the end of 2017);

$x_{8}$ - wind energy $(\mathrm{kWh})$ in new installations (from January 2018);

$x_{9}-$ generating energy from biogas $(\mathrm{kWh})$;

$x_{10}$ - generating energy from biogas in high-efficiency cogeneration with a total installed electrical capacity of less than $1 \mathrm{MW}$ in $(\mathrm{kWh})$;

$x_{11}$ - biogas energy generation (kWh) in new installations (from January 2018);

$x_{12}-$ generating energy from biofuels $(\mathrm{kWh})$;

$x_{13}$ - generating energy from biomass combustion (kWh) from existing boilers (until the end of 2017);

$x_{14}$ - energy generation from biomass combustion ( $\mathrm{kWh}$ ) from new boiler installations (from January 2018); 
$x_{15}$ - power generation from geothermal energy

$x_{16}$ - total annual electricity production from various energy sources $(\mathrm{kWh})$;

$x_{17}$ - energy willow of the yield $(\mathrm{kWh})$;

$x_{18}-$ yield value of miscatus $(\mathrm{kWh})$;

$x_{19}-$ poplar yield $(\mathrm{kWh})$

$x_{20}-$ sidaz yield $(\mathrm{kWh})$

$x_{21}$ - yields of Jerusalem artichoke $(\mathrm{kWh})$;

$x_{22}$ - size of rape grown for biofuels $(\mathrm{kWh})$

$x_{23}$ - size of cereals grown for biofuels $(\mathrm{kWh})$;

$x_{24}$ - the size of maise grown for biogas $(\mathrm{kWh})$;

$x_{25}$ - beet harvest for biogas (kWh).

The objective function (minimised) in the hydropower development model in the West Pomeranian Region consisted of three components:

$$
\begin{array}{ll}
- & \text { costs related to production, } \\
- & \text { costs related to certificates, } \\
- & \text { costs of EUA allowance prices, } \\
- & \text { loss of soil fertility. }
\end{array}
$$

In the optimisation model of hydropower development, only one function $(\mathrm{L}(\mathrm{x}))$ was minimised, which was a component of the above components.

The purpose function of the decision model is as follows:

$L(x)=0.69 x_{1}+0.90 x_{2}+0.07 x_{3}+0.07 x_{4}+0.27 x_{5}+0.11 x_{6}+0.11 x_{7}+0.03 x_{8}+0.56 x_{9}$ $+0.56 x_{10}+0.56 x_{11}+0.96 x_{12}+0.15 x_{13}+0.07 x_{14}+0.15 x_{15}+0.18 x_{17}+0.35 x_{18}+0.17 x_{19}+0.07 x_{20}+0.04 x_{21}+0.5 x_{22}$ $+0.34 x_{23}+0.5 x_{24}+0.21 x_{25} \rightarrow \min$

Side conditions are as follows:

The boundary conditions assume that all variables must be non-negative. $x_{1}+x_{2}+x_{3}+x_{4}+x_{5}+x_{6}+x_{7}+x_{8}+x_{9}+x_{10}+x_{11}+x_{12}+x_{13}+x_{14}+x_{15}=x_{16}$ - total energy production.

$x_{16} \geq 11956080000 \mathrm{kWh}$ - energy generation for the needs of the studied region.

$x_{3}+x_{4}+x_{5}+x_{6}+x_{7}+x_{8}+x_{9}+x_{10}+x_{11}+x_{12}+x_{13}+x_{14}+x_{15}=0.27 x_{15}-27 \%$ of total renewable energy production.

$x_{6}+x_{7}+x_{8} \geq 3575088000 \mathrm{kWh}$ - generating wind energy

$x_{8} \leq 840,000 \mathrm{kWh}$ - generating energy in newly created wind installations from 01/01/2018

$x_{9}+x_{10} \geq 41376000 \mathrm{kWh}$ - generating energy from biogas

$x_{13}+x_{14} \geq 238200000 \mathrm{kWh}$ - generating energy from biomass combustion.

$x_{9}+x_{10}=30450000 \times 23+10960000 \times 24$ - generating energy from biogas combustion.

$x_{11}+x_{12}=10500 \times 21+15000 \times 22$ - generating energy from the combustion of biofuels.

$x_{13}+x_{14}=238200000 \mathrm{kWh}$ - generating energy from biomass combustion.

$x_{15} \leq 811774000 \mathrm{KWh}$ generating energy from geothermal energy.

$x_{2} \leq 6907531938 \mathrm{kWh}$ - maximum energy generation from co-firing.

$x_{3} \geq 313770000 \mathrm{kWh}$ - hydropower generation.

$x_{4} \leq 319141000 \mathrm{kWh}$ - generating new hydropower

$x_{5} \geq 9590000 \mathrm{kWh}$ - minimum solar energy production.

Description of the model's construction is in the article by Rabe et al. (2019a).

\section{Discussion of Results}

Model optimisation with this objective function gives the following solutions given in Table 9.

Tab. 9. The results of optimisation model

\begin{tabular}{|c|c|c|c|c|c|c|c|c|c|c|c|c|c|c|c|}
\hline $\begin{array}{c}\text { Types of } \\
\text { energy }\end{array}$ & $\mathrm{x}_{1}$ & $\mathrm{x}_{2}$ & $\mathrm{x}_{3}$ & $\mathrm{x}_{4}$ & $\mathrm{x}_{5}$ & $\mathrm{x}_{6}$ & $\mathrm{x}_{7}$ & $\mathrm{x}_{8}$ & $\mathrm{x}_{9}$ & $\mathrm{x}_{10}$ & $\mathrm{x}_{11}$ & $\mathrm{x}_{12}$ & $\mathrm{x}_{13}$ & $\mathrm{x}_{14}$ & $\mathrm{x}_{15}$ \\
\hline $\begin{array}{c}\text { Energy } \\
\text { production }\end{array}$ & 0 & 7065.5 & 300.5 & 9.6 & 307.2 & 0 & 3575.08 & 95.5 & 30.45 & 12.96 & 54.06 & 0 & 238.2 & 160.2 & 106.83 \\
\hline $\begin{array}{c}\text { Energy } \\
\text { resources }\end{array}$ & $\mathrm{x}_{17}$ & $\mathrm{x}_{18}$ & $\mathrm{x}_{19}$ & $\mathrm{x}_{20}$ & $\mathrm{x}_{21}$ & $\mathrm{x}_{22}$ & $\mathrm{x}_{23}$ & $\mathrm{x}_{24}$ & $\mathrm{x}_{25}$ & & & & & & \\
\hline Crop size & 0 & 0 & 0 & 0 & 0 & 0 & 0 & 0.0423 & 0 & & & & & & \\
\hline
\end{tabular}

Considering the obtained solution, it can be noted that the total energy production is $11956.08 \mathrm{GWh}$ (i.e. covers the demand of the studied area), of which $7065.50 \mathrm{GWh}$ is energy production from co-firing. $300.55 \mathrm{GWh}$ 
is hydropower generated in hydropower plants created until December 31, 2018; $9.60 \mathrm{GWh}$ is hydropower generated in installations after 2018.

9.59 GWh is solar energy generated in installations until 2018, and $278.4 \mathrm{GWh}$ is energy generated after 2018. $3575.08 \mathrm{GWh}$ is wind energy generated in wind farms created until 31.12 .2018 , and $95.50 \mathrm{GWh}$ is energy produced in new wind farms created by the end of 2030 .

43.37 GWh through installations producing energy from agricultural biogas, and $54.06 \mathrm{GWh}$ is new energy generated from installations from biogas from sewage treatment plants and landfill biogas. $238.20 \mathrm{GWh}$ of energy was generated in existing biomass burning boilers. In contrast, $162.20 \mathrm{GWh}$ of existing boilers was established after 2018. 106.83 GWh is energy generated from geothermal power plants. The average cost of building one MW of energy will be PLN 9725018 .

\section{Conclusions}

Geothermal energy can be a reliable alternative energy source for the West Pomeranian Region. Its numerous benefits for the energy balance and ecology of this region are obvious and difficult to overestimate. Geothermal energy is part of the principles of sustainable development. It allows significantly lower use of non-ecological energy sources since it provides a cheap energy source. It can bring measurable benefits to local communities, local government authorities and tourists as well. Considering favorable geothermal conditions in the region under consideration, the development of geothermal plants should be expected.

However, new and updated policies and measures are necessary to overcome the main barriers to geothermal energy penetration in the West Pomeranian region. Currently available policies and measures are already targeting economic barriers and providing financial support in subsidies, etc. However, regulatory barriers such as unstable governmental policies and low public acceptance of geothermal energy projects due to Not In My Yard (NIMBY) syndrome and low awareness of the potential benefits of such technologies require additional measures such as demonstration projects and support for RERS infrastructure, including energy storage facilities. Also, support for geothermal R\&D would be important to overcome technological barriers to the penetration of these technologies.

\section{References}

Bertani, R. (2015). Geothermal power generation in world 2005-2014. Proceedings of World Geo-thermal Congress 2015. Melbourne, Australia

Boie, I., Fernandes, C., Frías, P., \& Klobasa, M. (2014). Efficient strategies for the integration of renewable energy into future energy infrastructures in Europe-An analysis based on transnational modeling and case studies for nine European regions. Energy Policy, 67, 170-185.

Borge-Diez, D., Colmenar-Santos, A., Pérez-Molina, C., \& López-Rey, A. (2015). Geothermal source heat pumps under energy services companies finance scheme to increase energy efficiency and production in stockbreeding facilities. Energy, 88, 821-836.

Bujakowski, W. (2003). Geothermal energy - a review of Polish experiences. Energy systems using clean, renewable energy sources on the example of geothermal energy. Cracow, Poland.

Büyüközkan, G., \& Güleryüz, S. (2017). Evaluation of renewable energy resources in Turkey using an integrated MCDM approach with linguistic interval fuzzy preference relations. Energy, 123, 149-163.

Collins, S., Deane, J.P., \& Gallachóir, Ó.B. Adding value to EU energy policy analysis using a multi-model approach with an EU-28 electricity dispatch model. Energy, 130, 433-447.

Colmenar-Santos, A., Palomo-Torrejón, E., Rosales-Asensio, E., \& Borge-Diez, D. (2018). Measures to remove geothermal energy barriers in the European Union. Energies, 11, 3202.

Cucchiella, F., D'Adamo, I., Gastaldi, M., \& Miliacca, M. (2018). Efficiency and allocation of emission allowances and energy consumption over more sustainable European economies. Journnal of Cleaner Production, 182, 805-817.

Dudin, M.N., Frolova, E.E., Protopopova, O.V., Mamedov, A.A., \& Odintsov, S.V. (2019). Study of innovative technologies in the energy industry: Nontraditional and renewable energy sources. Entrepreneurship and Sustainability Issues, 6(4), 1704-1713. http://doi.org/10.9770/jesi.2019.6.4(11)

Hollenbach, D.F., \& Herndon, J.M. (2001). Deep-Earth reactor: Nuclear fission, helium, and the geomagnetic field. Proceedings of the National Academy of Sciences, 98(20), 11085-11090. http://doi.org/10.1073/pnas.201393998

IEA. (2003). Renewables for Power Generation: Status and Prospects - 2003 Edition. Retrieved from: https://www.iea.org/reports/renewables-for-power-generation-status-and-prospects-2003-edition

Institute for Renewable Energy. (2011). Potential of wind energy and biomass in the West Pomeranian Voivodeship until 2020/2030. Warsaw, Poland.

Kaczmarczyk, M. (2009). Basics of geothermal energy. GLOBEnergia. 
Kasperowicz, R., Pinczyński, M., \& Khabdullin, A. (2017). Modeling the power of renewable energy sources in the context of classical electricity system transformation. Journal of International Studies, 10(3), $264-272$. http://doi.org/10.14254/2071-8330.2017/10-3/19

Kępińska, B. (2016). Overview of the state of utilization of geothermal energy in Poland in the years 2013-2015. Krakow: Geological Exploration Technology Geothermal Energy, Sustainable Development.

Kubski, P. (2017). Geothermal heating plant in Stargard Szczecinski and its fall, October 23 2017. Retrieved from: http://www.cire.pl/pliki/2/ciepl_geotermalna.pdf

Liao, H., Long, Y., Ming, T., Mardani, A., \& Xu, J. (2019). Low carbon supplier selection using a hesitant fuzzy linguistic span method integrating the analytic network. Transformations in Bussiness and Economics, 18(2), 67-88.

Lu, J., Ren, L., Yao, S., Rong, D., Skare, M., \& Streimikis, J. (2019). Renewable energy barriers and coping strategies: Evidence from the Baltic States. Sustainable Development, 28(1), 352-367. https://doi.org/10.1002/sd.2030

Maciej, J., \& Nowak, J. (2017). Analysis of the project Study on the potential and development of renewable energy sources in the West Pomeranian Region. Regional Office for Spatial Planning of the West Pomeranian Region, Szczecin, Poland.

Majorowicz, J. (1971). The course of geothermal degree values in Poland in the depth range 200-2500 m. Kwartalnik Geologiczny, 15(4).

Mariyakhan, K., Mohamued, E.A., Asif Khan, M., Popp, J., \& Oláh, J. (2020). Does the level of absorptive capacity matter for carbon intensity? Evidence from the USA and China. Energies, 13(2), 407. https://doi.org/10.3390/en13020407

Mikita, M., Kolcun, M., Špes, M., Vojtek, M., \& Ivančák, M. (2017). Impact of electrical power load time management at sizing and cost of hybrid renewable power system. Polish Journal of Management Studies, $15(1), 154-162$.

Ministry of Energy. (2018). Polish Energy Policy until 2040. Warsaw, Poland.

Olejnik, W. (2005). Hot water - a competitive energy carrier. Geothermal energy: for and against. Energia Gigawat.

Ozgener, O. (2010). Use of solar assisted geothermal heat pump and small wind turbine systems for heating agricultural and residential buildings. Energy, 35, 262-268.

Płocharski, M. (2017). Use of renewable energy sources in heating -elaboration for the needs of the Report on the condition, legal and economic conditions and prospects for the development of renewable energy sources in the West Pomeranian Region, Regional Office for Spatial Planning of the West Pomeranian Region, Szczecin 2017, pp. 24-35.

Popp, J., Kot, S., Lakner, Z., \& Oláh, J. (2018). Biofuel use: peculiarities and implications. Journal of Security and Sustainability Issues, 7(3), 477-493. https://doi.org/10.9770/jssi.2018.7.3(9)

Rabe, M. (2017). Analysis of the current formal and legal situation and market conditions and technical conditions in terms of the use and development of renewable energy sources in the West Pomeranian Voivodeship. Regional Office for Spatial Planning of the West Pomeranian Region, Szczecin, pp. 3-37.

Rabe, M., Streimikiene, D., \& Bilan, Y. (2019a). EU carbon emissions market development and its impact on penetration of renewables in the power sector. Energies, 12(15), 2961. https://doi.org/10.3390/en1215296

Rabe, M., Streimikiene, D., \& Bilan, Y. (2020). Model of optimization of wind energy production in the light of legal changes in Poland. Energies, 13(7), 1557. https://doi.org/10.3390/en13071557

Rabe, M., Streimikiene, D., \& Bilan, Y. (2019b). The concept of risk and possibilities of application of mathematical methods in supporting decision making for sustainable energy development. Sustainability, 11(4), 1018.

Raszkowski, A., \& Bartniczak, B. (2018). Towards sustainable regional development: Economy, society, environment, good governance based on the example of Polish Regions. Transformations in Business \& Economics, 17(2), 225-245.

Regional Office for Spatial Management of the West Pomeranian Region. (2018). Potential and use of renewable energy sources in the production of electricity and heat in the West Pomeranian Region. Szczecin, pp. 3660.

Rzepa, J. (2018). Potential resources and possibilities of using energy biomass for biogas production in the Zachodniopomorskie Voivodship, In: Regional and local energy biomass potential, M. Jasiulewicz (ed.). University of Technology Publishers of Koszalin University of Technology, Koszalin 2018, p. 59.

Romero-Rubio, C., \& de Andrés Díaz, J.R. (2015). Sustainable energy communities: A study contrasting Spain and Germany. Energy Policy, 85, 397-409.

Sala, K. (2018). Industrial use of geothermal energy in Poland on the example of the geothermal heating plant in Bańska Niżna. Works of the Industrial Geography Commission of the Polish Geographical Society, 32(2), p. 74

Savitz, R., \& Gavriletea, M.D. (2019). Climate change and insurance. Transformations in Business \& Economics, 18(1), 21-43. 
Shindina, T., Streimikis, J., Sukhareva, Y., \& Nawrot, Ł. (2018). Social and economic properties of the energy markets. Economics and Sociology, 11(2), 334-344. https://doi.org/10.14254/2071-789X.2018/11-2/23

Ślusarczyk, B., Baryń, M., \& Kot, S. (2016). Tire industry products as an alternative fuel. Polish Journal of Environmental Studies, 25(3), 1263-1270.

Sowiżdżał, A. (2009). Geological analysis and assessment of water resources and geothermal energy of the Mesozoic formation of the Szczecin Trough. PhD thesis written at the AGH University of Science and Technology. Stanisława Staszica, Krakow.

Stachel, A., \& Sołtysik, G. (2017). The largest geothermal power plants in the world and in Polan. Automation Electricity - Interferences, 8(4).

Stavytskyy, A., Kharlamova, G., Giedraitis, V., \& Šumskis, V. (2018). Estimating the interrelation between energy security and macroeconomic factors in European countries. Journal of International Studies, 11(3), 217238. https://doi.org/10.14254/2071-8330.2018/11-3/18

Szramka, R., \& Różycki, A. (1999). Geothermal energy, ERO Bulletin, No. 2, Krakow, March 1999, pp. $20-21$.

Tvaronavičienè, M., Prakapienė, D., Garškaitè-Milvydienė, K., Prakapas, R., \& Nawrot, Ł. (2018). Energy efficiency in the long-run in the selected European Countries. Economics and Sociology, 11(1), 245-254. https://doi.org/10.14254/2071-789X.2018/11-1/16 